THE VIRGIN OF CHARTRES 


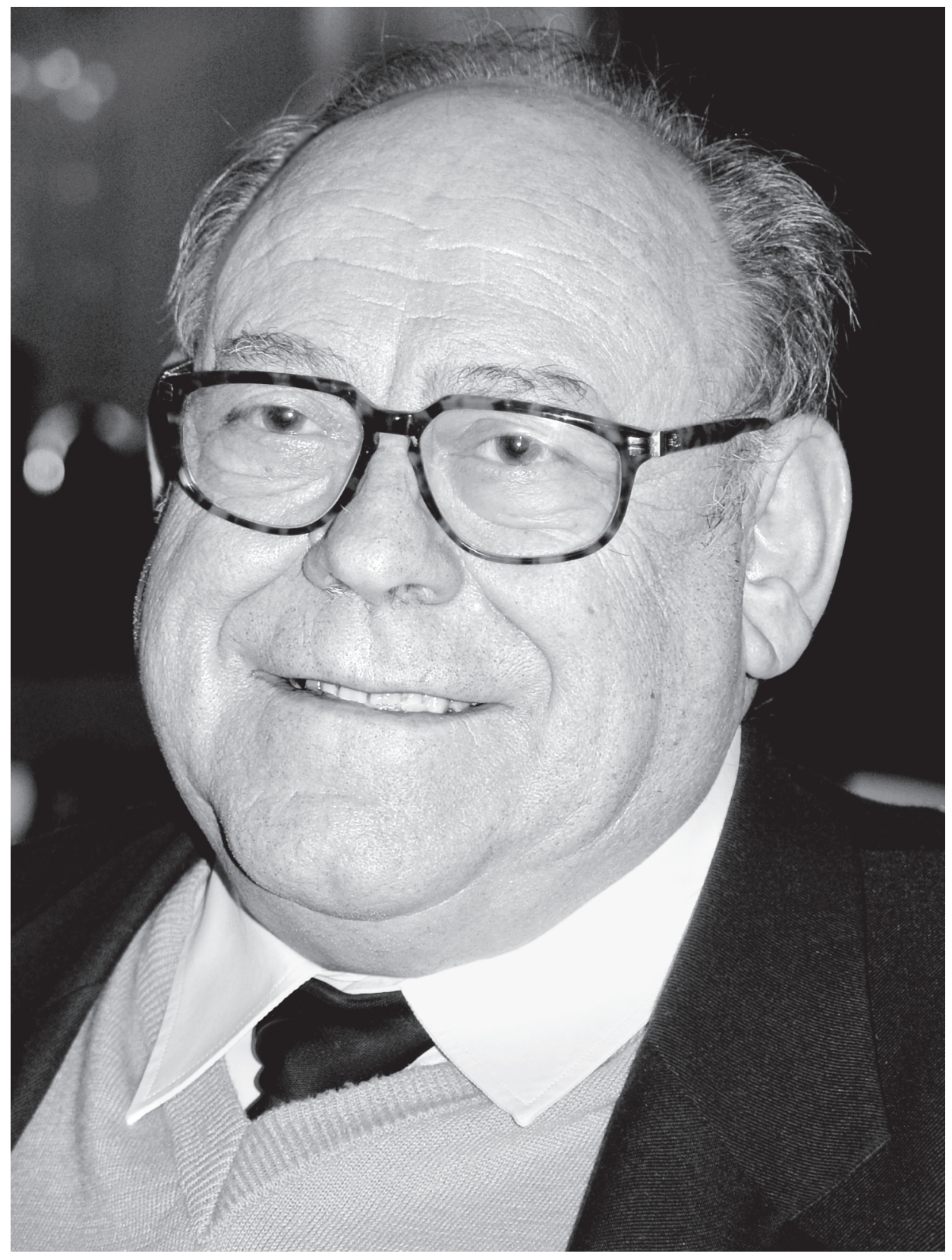

In memoriam Chanoine Pierre Bizeau,

Archiviste diocésain de Chartres, 1959-2007, d. 2008. Photo, de Feraudy. 


\title{
THE VIRGIN OF CHARTRES
}

Making History through Liturgy and the Arts

Margot E. Fassler

\author{
Yale \\ UNIVERSITY \\ PRESS
}

New Haven \& London 
Published with assistance from The Yale Institute of Sacred Music and from the foundation established in memory of Philip Hamilton McMillan of the Class of 1894, Yale College.

Copyright $@ 2010$ by Yale University.

All rights reserved.

This book may not be reproduced, in whole or in part, including illustrations, in any form (beyond that copying permitted by Sections 107 and 108 of the

U.S. Copyright Law and except by reviewers for the public press), without written permission from the publishers.

Set in Postscript Electra type by Tseng Information Systems, Inc.

Printed in the United States of America.

Library of Congress Cataloging-in-Publication Data

Fassler, Margot Elsbeth.

The Virgin of Chartres : making history through liturgy and the arts / Margot E. Fassler.

p. $\mathrm{cm}$.

Includes bibliographical references and index.

ISBN 978-0-300-11088-3 (cloth : alk. paper)

1. Chartres (France)-Church history. 2. Mary, Blessed Virgin,

Saint-Shrines-France-Chartres. I. Title.

$$
\begin{gathered}
\text { BR848.C47F37 } 2010 \\
232.91^{\prime} 709445124-\mathrm{dc} 22 \\
2009035845
\end{gathered}
$$

A catalogue record for this book is available from the British Library.

This paper meets the requirements of ANSI/NISO Z39.48-1992 (Permanence of Paper).

It contains 30 percent postconsumer waste (PCW) and is certified by the Forest Stewardship Council (FSC). 